Agro-Science Journal of Tropical Agriculture, Food, Environment and Extension Volume 19 Number 3 (July 2020) pp. $15-18$

ISSN 1119-7455

\title{
DETERMINANTS OF HOUSEHOLD PREFERENCE FOR BEEF TO PORK IN UMUAHIA METROPOLIS OF ABIA STATE, NIGERIA
}

\author{
*Okoronkwo F.C., Efedua J.C. and Amusa T.A. \\ Department of Agricultural Economics, \\ Michael Okpara University of Agriculture, Umudike, PMB 7267, Abia State, Nigeria \\ *Corresponding author's email: simeononya@yahoo.com, francischijioke31@gmail.com, joshuaefeduac@gmail.com
}

\begin{abstract}
The study ascertained the determinants of households' preference for beef to pork in Umuahia Metropolis of Abia State, Nigeria. Using multi-stage random sampling procedure, data were collected from eighty household heads for the study. Data collected were analyzed using descriptive statistics, ordinary least square and probit regression analysis. Findings from the study showed that beef was most preferred with $63.75 \%$ of households indicated preferences for beef to pork while $36.25 \%$ of households preferred port to beef. The study also revealed age of household head, and price of meat negatively influenced meat consumption while household size and average monthly income had positive influence and the $R^{2}$ was 0.675 which implied $67.5 \%$ of the variation in the meat consumption was explained by the independent variables. From the probit regression model the results showed age of household heads and price of pork had a negative coefficient and were significant at $10 \%$ and $5 \%$ level of probability respectively, while household size, education level, and household income had positive coefficient and were significant at 1\%, 5\%, and 1\% level of probability, respectively. The Chi square was 135.485 which indicated the goodness of fit for the equation and was significant at 1\% level of probability. The study recommended beef marketing as a good venture in the study area; beef was most preferred meat in the study. Hence, it is recommended that unemployed persons should be encouraged to venture into beef marketing; also, there is huge potential for pork marketing in the study area.
\end{abstract}

Key words: preferences, household, beef, pork

\section{INTRODUCTION}

Meat is one of the major products of livestock industry in Nigeria. It is generally defined as the skeletal muscle from animals, including the connective tissues and fat that are naturally associated with the muscle and may also include all the edible parts of an animal (Gambo et al., 2010). There are different kinds of meat depending on the source from which they are obtained, for example, mutton from sheep, chevon from goat, beef from cattle, pork from pig and chicken from birds (Soniran and Okubanjo, 2002).

Meat according to Udoh and Akintola (2003) is the most important source of animal protein in Nigeria. Meat is the most valuable livestock product and for many people, serves as their first choice source of animal protein (Tsegay, 2012). In many developing countries, especially Nigeria meat is widely consumed as a source of protein; it is either eaten cooked or processed into other forms to avoid associated spoilage (Olaoye and Onilude, 2010).

Despite the important of meat as a source of protein with high biological value, there is preference for different meat types. This is because meat consumers are rational beings and are affected by many external inputs that can modulate their knowledge, emotional, and even power to make choice. Therefore, knowledge and attitudes about diet and meat products influence people's choices, especially the likelihood of consuming specific types of meat (Guenther et al., 2005).

In addition, consumers (households) have a positive attitude toward specific nutritional improvements of meat and meat products such as reducing fat (Guàrdia et al., 2006). However, for most consumers of meat products, the way the products taste and look (i.e., the sensory properties) are the most important motivators for preferring and purchasing a meat product.

In this view, this study aimed to estimate the determinants of household preference for beef to pork in Umuahia Metropolis of Abia State and the specific objectives were to: examine level of households' preference for beef to pork, estimate the determinants of households' meat consumption and the determinants of households' preference for beef to pork in the study area. 


\section{MATERIALS AND METHODS}

This study was carried out in Umuahia metropolis of Abia State which comprises two local government The two LGAs combined have a population of 359,230 according to the 2006 Nigerian census. Umuahia is located latitude $7^{\circ} 29^{\prime} \mathrm{N}$ and longitude $5^{\circ} 32^{\prime} \mathrm{E}$. The study area was characterized by fertile soil and varying temperature of $27^{\circ} \mathrm{C}$ and $30^{\circ} \mathrm{C}$. A multistage stage random sampling procedure was used in the study. The first stage involved random selection of two autonomous communities from each of the two LGAs making four communities in all. The second stage involved random selection of two villages from each of the four selected autonomous communities making eight villages for the study. The third stage involved random selection of 10 households from the eight selected villages. These give a total of 80 households for the study.

\section{Analytical Techniques}

The level of households' preference for beef to pork was determined by the use of percentage. The determinants of households' meat consumption were analyzed by the use of ordinary least square regression analysis, while the determinants of households' preference for beef to pork were analyzed by the use of probit regressions analysis.

\section{Ordinary Least Square Model Specification}

$\mathrm{Y}=\mathrm{f}\left(\mathrm{X}_{1}, \mathrm{X}_{2}, \mathrm{X}_{3}, \mathrm{X}_{4}, \mathrm{X}_{5}, \mathrm{X}_{6}, \mathrm{X}_{7}, \mathrm{et}_{\mathrm{i}}\right)$

where $Y$ is quantity of meat consumed $(\mathrm{kg}), \mathrm{F}$ is function, $\mathrm{X}_{1}$ is age of the household head (years), $\mathrm{X}_{2}$ is marital status (married $=1$, single $=0$ ), $X_{3}$ is household size (number), $\mathrm{X}_{4}$ is education level (years), $X_{5}$ is income ( $), X_{6}$ is occupation (farmers $=1$, otherwise $=0), X_{7}$ is meat price $(\#)$, et is error term.

\section{Probit Model Specification}

The probit model is a statistical probability model with two categories in the dependent variable (Liao, 2011). Probit analysis is based on the cumulative normal probability distribution. The binary dependent variable $y$ takes as values of 0 and 1 . The outcomes of $y$ are mutually exclusive and exhaustive. This $y$ depends on $\mathrm{k}$ observable variables xk where $k=1$ (Aldrich and Nelson, 1984). While the values of 0 and 1 were observed for the dependent variable in the probit model, there was a latent, unobserved continuous variable $\mathrm{y}^{*}$, defined thus: areas (LGAs); Umuahia North and Umuahia South.

$$
\mathrm{y}^{*}=\sum_{k=1}^{k} \beta \mathrm{kxk}+\varepsilon
$$

where $\varepsilon$ is $\operatorname{IN}\left(0, \sigma^{2}\right)$ The dummy variable y was observed and was determined from $\mathrm{y}^{*}$ as follows:

$$
\mathrm{Y}=\left\{\begin{array}{l}
1 \text { if } y *>0 \\
0 \text { otherwise }
\end{array}\right.
$$

The point of interest relates to the probability that $y$ equals 1 . From the above equations, we see that:

$$
\begin{aligned}
& \operatorname{Prob}(\mathrm{y}=1)=\operatorname{Prob}\left(\sum_{k=1}^{k} \beta \mathrm{kxk}+\varepsilon>0\right)=\operatorname{Prob} \\
& \left.\left(\varepsilon>\sum_{k=1}^{k} \beta \mathrm{kxk}\right)=1-\Phi\left(-\sum_{k=1}^{k} \beta \mathrm{kxk}\right) \ldots \ldots \ldots \ldots . .4\right)
\end{aligned}
$$

where $\Phi$ was the cumulative distribution function of $\varepsilon$ (Liao). Then $Y$ is the probability of a household preference for one of the meat types (beef and pork), thus $Y$ is household preference; $Y=1$ for beef and 0 for pork. Hence, the model is explicitly stated as:

$$
\begin{aligned}
& \mathrm{Y}=\mathrm{B}_{0}+\mathrm{B}_{1} \mathrm{X}_{1}+\mathrm{B}_{2} \mathrm{X}_{2}+\mathrm{B}_{3} \mathrm{X}_{3}+\mathrm{B}_{4} \mathrm{X}_{4}+\mathrm{B}_{5} \\
& \mathrm{X}_{5}+\ldots+\mathrm{B}_{8} \mathrm{X}_{8}+\mathrm{et}_{\mathrm{i}} \ldots \ldots \ldots \ldots \ldots \ldots \ldots \ldots \ldots \ldots \ldots \ldots \ldots \ldots \ldots \ldots \ldots \ldots \ldots \ldots \ldots \ldots \ldots \ldots
\end{aligned}
$$

where $\mathrm{B}_{0}$ is the intercept, $\mathrm{B}_{1}$ to $\mathrm{B}_{10}$ are regression coefficients, $X_{1}$ is age of household head (years), $X_{2}$ is marital status (married $=1$, single $=0$ ), $X_{3}$ is gender $($ male $=1$, female $=0), X_{4}$ is household size (number of people in the house), $\mathrm{X}_{5}$ is educational level (number of years), $X_{6}$ is income $(\#), X_{7}$ is occupation (farmers $=1$, others $=0$ ), $X_{8}$ is price of pork ( $)$, and $\mathrm{et}_{\mathrm{i}}$ is error term.

\section{RESULTS AND DISCUSSION \\ Level of Households Preference for Beef to Pork in the Study Area}

The results in Table 1 show the level of households' preference for beef to pork in the study area. The results in Table 1 showed that beef was most preferred with $63.75 \%$ of households indicated preferences for beef to pork while $36.25 \%$ of households preferred port to beef in the study area.

Table 1: Level of household preference for beef to pork

\begin{tabular}{lll}
\hline Meat types & Frequency & Percentage \\
\hline Pork & 29 & 36.25 \\
Beef & 51 & 63.75 \\
Total & 80 & 100 \\
\hline \multicolumn{2}{l}{ Source Field survey 2017 }
\end{tabular}

Table 2: Determinants of meat consumption

\begin{tabular}{lllll}
\hline Variables & Linear & Exponential & Semi-log & Double log+ \\
\hline Constant & $0.053(0.042)$ & $0.528(0.434)$ & $12.647(1.552)$ & $9.498(1.311)$ \\
Age & $-0.003(-0.029)$ & $-0.103 * *(-0.931)$ & $-0.048(-0447)$ & $-0.060 *(-0.578)$ \\
Marital status & $0.032(0.223)$ & $0.012(0.080)$ & $0.026(0.302)$ & $0.013(0.148)$ \\
Household size & $-0.052(-0.507)$ & $-0.208 *(-1.936)$ & $-0.017 *(-0.158)$ & $-0.159 * *(-1.507)$ \\
Education & $0.193 *(2.272)$ & $0.270 *(3.055)$ & $0.094(1.014)$ & $0.137(1.530)$ \\
Income & $0.629 *(7.347)$ & $0.570 *(6.391)$ & $0.683 *(7.659)$ & $0.706 *(8.155)$ \\
Occupation & $0.193(2.244)$ & $0.211(2.362)$ & $0.197(2.165)$ & $0.178(2.018)$ \\
Price of meat & $-0.015(-0.182)$ & $-0.050(-0.598)$ & $-0.047(-0.555)$ & $-0.007 *(-0.088)$ \\
$\mathrm{R}^{2}$ & 0.566 & 0.530 & 0.613 & 0.675 \\
Adjusted R ${ }^{2}$ & 0.504 & 0.462 & 0.551 & 0.634 \\
F - ratio & 9.013 & 7.781 & 9.854 & 15.146 \\
\hline Source: Field Survey Data, 2017$)^{*}, * *$ and ${ }^{* * *}$ are for 10,5 and $1 \% P$ levels, respectively. Figures in parenthesis are the t-ratios, ${ }^{+}$the lead equation
\end{tabular}


This result agreed with earlier reports by Ikpi (1990), FAO (2006), Akinwumi et al. (2011), and Emakoro and Adamasun (2012) who stated that beef was the most consumed meat in Nigeria. FAO (2013) also supported that beef accounts for about $50 \%$ of the total meat consumption in Nigeria, while Nwakpu and Ugwu (2004) and Odo et al. (2004) gave religious and socio - cultural taboos as factors that affect the consumption of pork. In addition, Odo et al. (2004) also stated that in the study area, pork had low preference because of religion and sociocultural reasons which led to its low patronage, and also studies by Teklebrhan (2012) have shown pork consumption was negatively influenced by religion and socio-cultural taboos.

\section{Determinants of Meat Consumption in the Area}

The result for the determinants of meat consumption in the study area is shown in Table 2. The double log function was chosen as lead equation based on the number of significant independent variables, the Fratio, the value of the $\mathrm{R}^{2}$ and conformity with a priori expectations. The F-ratio (15.146) was significant at $1 \%$ and it showed the goodness of fit of the regression line. The $\mathrm{R}^{2}$ was 0.675 which implies that $67.5 \%$ of the variation in the dependent variable (meat consumption) was explained by the independent variables (age of the household heads, marital status, household size, education level, average monthly income, occupation, and price of meat).

The study also revealed age of household head, and price of meat negatively influenced meat consumption. This implies that household heads consume less meat as they advance in age. A year increase in age of the household will reduce meat consumption by $0.06 \mathrm{Kg}$. The negative influence of meat price was consistent with economic theory of demand which state that price and quantity demanded are inversely related ceteris paribus. Furthermore, household size had negative influence. The result of the average monthly income agreed with Akinwumi et al. (2011) and Ikpi (1990) results, that an increase in family income would translate to an increase in the quantity of meat consumed.

\section{The Determinant of Households' Preference for Beef to Pork in Study Area}

The results in Table 3 show the determinants of households' preference for beef to pork in study area.
The value 135.485 of Chi square and Likelihood ratio was significant at $1 \%$ level of probability and it indicates the goodness of fit of the regression line for the equation. This implied that the explanatory variables; age, household size, education level, marital status, income, gender, occupation, and price of pork strongly influenced the preference of households for beef to pork in the study area.

The result also showed age of household heads and price of pork had a negative coefficient and were statistically significant at $10 \%$ and $5 \%$ level of probability while household size, education level, and income were positively signed and were statistically significant at $1 \%, 5 \%$, and $1 \%$ level of probability respectively.

The coefficient $(-0.021)$ of age of household heads was negatively signed. It implied that an increase in age will decrease the probability of preference for beef to pork. However, the positive sign on the coefficient (0.019) household size implied an increase in household size increased the probability of preference for beef to pork in the metropolis. This finding agreed with Yakubu et al. (2013) larger the household size the more the consumption and higher the preference for beef in the Sokoto metropolis.

The coefficient (0.019) of household head education level was positive and it implies that increase in education level of the household heads will increase the probability their preference for beef relative to pork as an important source of protein in the study area. This finding was in line with Amimo et al. (2011), who reported that education empowers people, strengthens their abilities to meet their needs and increase their productivity and potential to improve their quality of life.

The positive coefficient (0.012) of average household income implies that the increase would likely increase the preference for beef in the study area. The result was in line with a priori expectation and it agreed with Gambo et al. (2010) report that income of the household head increases the preference for beef in Maiduguri metropolitan, North-West, Nigeria. The negative sign of the coefficient $(-0.001)$ of price of pork implies that the probability of households' preference for pork increase as the price of pork decreases. This finding agrees with Yakubu et al. (2013) that expected expenditure on beef substitutes tends to decrease preference for beef.

Table 3: Determinants of household preference for beef to pork

\begin{tabular}{lllll}
\hline Variables & Estimate & Standard error & Z-statistic & Significant \\
\hline Age & $-0.021^{*}$ & 0.011 & -1.951 & 0.061 \\
Marital status & -0.062 & 0.145 & -0.426 & 0.670 \\
Gender & 0.098 & 0.293 & 0.332 & 0.740 \\
Household size & $0.019^{* * *}$ & 0.047 & 0.409 & 0.002 \\
Education & $0.019^{* *}$ & 0.018 & 1.067 & 0.044 \\
Income & $0.012^{* * *}$ & 0.262 & 0.046 & 0.004 \\
Occupation & 0.010 & 0.018 & 0.546 & 0.185 \\
Price of pork & $-0.001 * *$ & 0.001 & -0.605 & 0.041 \\
Intercept & 0.066 & 1.456 & 0.045 & 0.964 \\
Chi square & $135.485^{* * *}$ & & & \\
\hline
\end{tabular}

Source: Field Survey Data, 2017 . $* 10 \%$ level of significance; $* * 5 \%$ level of significance; $* * * 1 \%$ level of significance. 


\section{CONCLUSION}

Based on the results, it is concluded that beef is the most preferred meat by households in the Umuahia metropolis in southeastern Nigeria. Age of household head and price of meat negatively influenced meat consumption while household size and average monthly income had positive influenced. The preference for beef to pork is positively influenced by household size, education level, and income while it is negatively influenced by the age of household heads and price of pork in the study area.

\section{RECOMMENDATIONS}

(i) Marketing of beef will be a good venture in Umuahia Metropolis of Abia state. Therefore, marketing activities should be centered more on ensuring stable price, because when household views decrease in the price of pork as a result of increase in the price of beef may lead to the increase in the probability level of household preference for pork to beef. It is also recommended that government price intervention programme should be introduced in order to ensure stable price of beef.

(ii) Beef was the more preferred meat in the study. Hence, it is recommended that unemployed persons be encouraged to go into beef marketing as a business.

(iii) There is also huge potential for pork marketing in the study area. Awareness should be created about pork as an important animal protein, due to the health implications and being cheaper. Large households are also encouraged to consume more of pork.

\section{REFERENCES}

Akinwumi A.O., Odunsi A.A., Omojola A.B., Aworemi J.R. and Aderinola O.A. (2011). Consumer perception and preference for meat types in Ogbomoso Area of Oyo State, Nigeria. Int. J. Appl. Agric. Api. Res., 7 (1-2), 96-106

Aldrich J.H. and Nelson F.D. (1984). Linear Probability, Logit and Probit Model: Quantitative Application in the Social Science-Sera Miller McCun. Sage Pub. Inc, University of Minnesota and Iola, London

Amimo J.O., Thumbi S., Inyangala B.O., Junga J.O. and Mosi R.O. (2011). Socio- economic characteristics and perceptions of cattle keepers and constraints to cattle production in Western Kenya. Livestock Res. Rural Dev., 23 (6), Retrieved from: http://www.Irrd.org/Irrd23/6/amim23138.htm

Emakoro C.O. and Amadasun O.J. (2012). Analysis of beef marketing in Benin-city, Nigeria. Nigerian $J$. Agric, Food Environ., 8 (3), 26-31
FAO (2006). Food and Agriculture Organization of the United Nations. FAO Statistical Database. http://aps. FAO.org. cited 16/06/06

FAO (2013). FAOSTAT Data. Food and Agriculture Organization (FAO), Rome. Accessed http://faostat.external.fao.org/default. October, 2013

Gambo B.G., Raufu I.A. and Ambali A.G. (2010). Residents in Borno State and their meat preference among ruminant species. Afr. J. Gen. Agric., 6 (2), 53-58

Guàrdia M.D., Guerrero L., Gelabert J., Gou P. and Arnau J. (2006). Consumer attitude towards sodium reduction in meat products and acceptability of fermented sausages with reduced sodium content. Meat Sci., 73, 484-490

Ikpi A.E. (1990). Livestock Marketing and Consumption in Nigeria from 1970-1989. An Unpublished Research in the Department of Agricultural Economics, University of Ibadan, Ibadan, Nigeria

Liao C.H. (2011). How to improve research quality? Examining the impacts of collaboration intensity and member diversity in collaboration networks. Scientometrics, 86 (3), 747-761

Nwakpu P.E. and Ugwu L.L.C. (2004). Contribution of pork to meat supply in Ebonyi State, Nigeria. Proceedings of the 9th Annual Conference of Animal Science Association of Nigeria held between 13 and 16th September, 211-213

Odo B.I., Marire B.N., Alaku S.O., Akpa M.O., Nwosu D.C. and Anikwe M.A. (2004). Pig meat consumption in Enugu metropolis. Proceedings of the 9th Annual Conference of Animal Science Association of Nigeria held between 13 and 16th September, pp. 211-213

Olaoye O.A. and Onilude A.A. (2010). Investigation on the potential use of biological agents in extension of fresh beef in Nigeria. World J. Microbiol. Biotechnol., 26, 1445-1454. DOI; 10.1007/s11274-010-0319-5

Soniran O.G. and Okubanjo A.O. (2002). Physicochemical and sensory characteristics of pork loin roast cooked to three internal temperatures. Nigeria J. Anim. Prod., 29 (1), 138-141

Teklebrhan T. (2012). Consumer perception and preferences of meat types in Harah and Haramaya towns, Ethiopia. J. Microbiol. Biotechnol. Food Sci., 2 (3), 959-969

Tsegay H. (2012). Consumer perception and preferences of meat types in Harare and Haramaya province, Ethiopia. J. Microbiol., Biotechnol. Food Sci., 2 (3), 959

Udoh E.J. and Akintola J.O. (2003). An analysis of beef demand in Nigeria Urban cities. Global J. Pure Appl. Sci., 9 (1), 7-12

Yakubu N., Garba A.A., Jibir S. and Zubairu A. (2013). Factors influencing consumer preference for fresh beef in Sokoto Metropolis, Nigeria. Int J. Appl. Agric. Api. Res., 9 (1 and 2), 106-112 